Article

\title{
Effect of Coal Rank on Various Fluid Saturations Creating Mechanical Property Alterations Using Australian Coals
}

\author{
Mandadige Samintha Anne Perera *, Ashani Savinda Ranathunga and \\ Pathegama Gamage Ranjith
}

Deep Earth Energy Laboratory, Department of Civil Engineering, Monash University, Building 60, Melbourne, Victoria 3800, Australia; ashani.ranathunga@monash.edu (A.S.R.); ranjith.pg@monash.edu (P.G.R.)

* Correspondence: samintha.perera@monash.edu; Tel.: +61-399-058-902; Fax: +61-399-054-982

Academic Editor: Thomas E. Amidon

Received: 13 April 2016; Accepted: 1 June 2016; Published: 8 June 2016

\begin{abstract}
During $\mathrm{CO}_{2}$ sequestration in deep coal seams, the coal mass may be subjected to various fluid $\left(\mathrm{CO}_{2}, \mathrm{~N}_{2}\right.$, etc. $)$ saturations. Therefore, in order to maintain the long-term integrity of the process, it is necessary to identify the mechanical responses of preferable coal seams for various fluid saturations. To date, many studies have focused on the $\mathrm{CO}_{2}$ saturation effect on coal mass strength and less consideration has been given to the influence of other saturation mediums. Hence, this study aims to investigate coal's mechanical responses to water and $\mathrm{N}_{2}$ saturations compared to $\mathrm{CO}_{2}$ saturation and to determine the effect of coal-rank. A series of unconfined compressive strength (UCS) tests was conducted on Australian brown and black coal samples saturated with water and $\mathrm{N}_{2}$ at various saturation pressures. An advanced acoustic emission (AE) system was utilized to identify the changes in crack propagation behaviors under each condition. According to the results, both $\mathrm{CO}_{2}$ and water act similarly with coal by enhancing the ductile properties of the coal mass and this mechanical weakening is greater for high-rank coal. Conversely, $\mathrm{N}_{2}$ saturation slightly enhances coal strength and delays crack propagation in coal and this strength enhancement can be improved by increasing the $\mathrm{N}_{2}$ saturation pressure.
\end{abstract}

Keywords: coal rank; mechanical properties; $\mathrm{N}_{2}$ saturation; $\mathrm{CO}_{2}$ saturation; water saturation

\section{Introduction}

The process of enhanced coal bed methane (ECBM) recovery is being implemented and tested as a viable option to store and reduce the amount of anthropogenic carbon dioxide $\left(\mathrm{CO}_{2}\right)$ in the Earth's atmosphere, as well as for the recovery of useful coal bed methane $\left(\mathrm{CH}_{4}\right)$ gas [1-7]. Overall, the ECBM process involves introducing $\mathrm{CO}_{2}$ through injecting wells into deep coal seams and this $\mathrm{CO}_{2}$ then acts as a displacing gas, which allows the already adsorbed $\mathrm{CH}_{4}$ to be desorbed from the coal matrix. Finally, $\mathrm{CH}_{4}$ is obtained through a recovery well and used to produce energy in a cost-effective and environmentally friendly way.

However, according to previous studies [1-3,6,8-12], this $\mathrm{CO}_{2}$-ECBM process leads to $\mathrm{CO}_{2}$ adsorption-induced coal matrix alterations, which in turn affect its hydro-mechanical properties. Particularly in the geomechanical respect, the coal mass becomes weaker with the substitution of existing adsorbate $\mathrm{CH}_{4}$ with the highly chemically potential $\mathrm{CO}_{2}$ [13,14]. According to Perera et al. [15], Ranathunga et al. [16] and Vishal et al. [17], the inherent brittleness of the coal mass becomes ductile with the plasticization effect of coal with the adsorption of $\mathrm{CO}_{2}$, and this phenomena is higher for super-critical $\mathrm{CO}_{2}$ (beyond the critical temperature of $\mathrm{CO}_{2}-31.8^{\circ} \mathrm{C}$ and the critical pressure of $\mathrm{CO}_{2}-7.38 \mathrm{MPa}$ ). Generally, potential $\mathrm{CO}_{2}$-ECBM reservoirs are located deep underground, where $\mathrm{CO}_{2}$ is in its super-critical state [2]. Hence, the strength reduction may be hazardous for the overall stability of coal 
reservoirs, mainly in regard to the cap rock's stability [18]. Table 1 provides a summary of previous studies on the identification of the geomechanical responses of different coal types under various $\mathrm{CO}_{2}$ adsorption conditions. Those studies show that the coal mass is weakened by $\mathrm{CO}_{2}$ adsorption and the effect is relatively higher for super-critical $\mathrm{CO}_{2}$ for any type of coal. For instance, Australian brown coal shows $20.92 \%$ and $23.84 \%$ of unconfined compressive strength (UCS) and Young's modulus reduction for sub-critical $\mathrm{CO}_{2}$ saturation at $6 \mathrm{MPa}$ and $57.32 \%$ and $41.14 \%$ UCS and Young's modulus reduction for super-critical $\mathrm{CO}_{2}$ saturation at $8 \mathrm{MPa}$ respectively [16]. For Australian black coal, when the $\mathrm{CO}_{2}$ saturation pressure increased from $6 \mathrm{MPa}$ (sub-critical) to $8 \mathrm{MPa}$ (super-critical), the UCS reduction was increased from $56.67 \%$ to $77.58 \%$ and the Young's modulus reduction was increased from $42.23 \%$ to $70.27 \%$ [15]. This is because the higher adsorption potential of super-critical $\mathrm{CO}_{2}$ results in greater coal matrix alterations, causing greater strength reductions in the coal structure.

Table 1. Geomechanical responses of different coal types under various $\mathrm{CO}_{2}$ saturation conditions.

\begin{tabular}{|c|c|c|c|c|c|c|c|c|c|}
\hline Temperature $\left({ }^{\circ} \mathrm{C}\right)$ & $\begin{array}{c}\text { Pressure } \\
\text { (MPa) }\end{array}$ & $\begin{array}{l}\mathrm{CO}_{2} \text { Phase } \\
\text { Condition }\end{array}$ & Coal Type & $\begin{array}{l}\text { Coal } \\
\text { Rank }\end{array}$ & $\begin{array}{c}\text { UCS } \\
\text { (MPa) }\end{array}$ & $\begin{array}{c}\Delta \mathrm{UCS} \\
(\%)\end{array}$ & $\begin{array}{c}\mathrm{E} \\
(\mathrm{MPa})\end{array}$ & $\Delta \mathrm{E}(\%)$ & Reference \\
\hline 35 & 0 & - & Lignite $^{1}$ & Low & 2.40 & - & 41.60 & - & [16] \\
\hline Room temperature & 0 & - & Bituminous $^{3}$ & High & 15.29 & - & 5340 & - & [17] \\
\hline Room temperature & 1 & Gas & Lignite $^{1}$ & Low & 2.34 & 2.09 & 40.32 & 4.73 & [16] \\
\hline 35 & 2 & Gas & Lignite $^{1}$ & Low & 2.25 & 5.86 & 35.08 & 17.11 & [16] \\
\hline 35 & 4 & Gas & Lignite $^{1}$ & Low & 2.15 & 10.04 & 33.65 & 20.49 & [16] \\
\hline 33 & 4.5 & Gas & Bituminous ${ }^{2}$ & High & 15.80 & 52.12 & 2300 & 37.84 & [15] \\
\hline 35 & 6 & Gas & Lignite $^{1}$ & Low & 1.89 & 20.92 & 32.23 & 23.84 & [16] \\
\hline 33 & 6 & Gas & Bituminous $^{2}$ & High & 14.30 & 56.67 & 2130 & 42.43 & [15] \\
\hline 35 & 8 & Super critical & Lignite $^{1}$ & Low & 1.02 & 57.32 & 24.91 & 41.14 & [16] \\
\hline 33 & 16 & Super critical & Bituminous $^{2}$ & High & 13.95 & 57.64 & 1570 & 57.58 & [15] \\
\hline
\end{tabular}

Interestingly, although both low and high rank coal samples behave similarly under $\mathrm{CO}_{2}$ saturation, low rank coal exhibits a comparatively lower strength reduction compared to high rank coal (see Table 1). According to Table 1, the average reduction of UCS is around $29 \%$ for the tested Australian brown coal and that of the tested Australian black coal is around 61\%. Further, the Young's modulus of the tested Australian brown coal exhibits around $26 \%$ average reduction, while the tested Australian black coal shows an average reduction of around $47 \%$. In addition, for $3 \mathrm{MPaCO}_{2}$ saturation, the tested Australian brown coal shows a UCS reduction of $9.21 \%$ and Young's modulus reduction of $20.18 \%$, while the tested Indian black coal shows $17.6 \%$ and $26.2 \%$ reductions in UCS and Young's modulus, respectively (see Table 1). The reason is the naturally existing well-developed cleat system in high rank coal that acts as a locus for $\mathrm{CO}_{2}$ movement, permitting a greater matrix alteration compared to low rank coal with a less-developed cleat system.

It is also important to study the geomechanical behavior of the coal mass under other saturation mediums such as water and nitrogen $\left(\mathrm{N}_{2}\right)$. Moisture in a rock mass is known to affect the strength of rock by reducing its surface energy [19] and consequently softening the bond structure. Hence, it is vital to identify how different types of coals behave under the effect of moisture. In the case of $\mathrm{N}_{2}$ saturation, researchers [3,20-23] have found that $\mathrm{N}_{2}$ has the ability to recover $\mathrm{CO}_{2}$ adsorption-induced coal matrix alteration, which eventually enhances the hydraulic properties of the coal matrix. Perera, Ranjith and Peter [24] have investigated the behavior of $\mathrm{N}_{2}$ and $\mathrm{CO}_{2}$ saturation on low-rank brown coal and observed around 2\% increase in strength and Young's modulus for $3 \mathrm{MPa} \mathrm{N}_{2}$ saturation. This is quite a low pore pressure condition and it is important to see this effect under much greater pore pressure conditions for possible field application. Regarding the rank effect, although there 
have been some studies to date $[16,25]$ on the effect of $\mathrm{CO}_{2}$ saturation on different ranks of coal, none of them has considered the rank-dependent mechanical behavior of coal mass under $\mathrm{N}_{2}$ saturation, particularly under high saturation pressure conditions. Therefore, it is interesting to investigate how coal mechanical property alterations vary under high $\mathrm{N}_{2}$ saturation conditions and the rank effect on them, which will in turn enable more reliable applications for field projects. This study therefore intends to fill this gap by determining the effect of water and $\mathrm{N}_{2}$ saturation on the strength of low rank coal (lignite) and high rank coal (bituminous). The main objective of the present study is to distinguish the effects of water and $\mathrm{N}_{2}$ saturation on the mechanical properties of different coal ranks.

\section{Methodology}

\subsection{Samples Used for Testing}

Brown coal (lignite) samples acquired from the Hazelwood mine in the Latrobe Valley, Victoria, Australia from approximately 50-75 m depth (from the ground level) were employed to represent low rank coal, while black coal (bituminous) samples collected from the Appin coal mine in the Southern Sydney basin, Australia from approximately $400 \mathrm{~m}$ depth (from the ground level) were utilized to represent high rank coal for this study. Both types of coal were obtained immediately after mining and therefore had been subjected to minimal environmental effects such as dusting, water evaporation or sunlight. The samples used for the present study were the same specimens obtained from the same coal blocks used by Perera, Ranjith and Viete [15] (black coal) and Ranathunga et al. [16] (brown coal) and the water content of the blocks was checked before coring new samples to ensure that the coal blocks were not subjected to any moisture loss. The physical properties of the samples used are shown in Table 2. Samples of $38 \mathrm{~mm}$ in diameter and $76 \mathrm{~mm}$ in height were used for testing purposes and the samples were maintained in a fog room wrapped in plastic wraps (after coring from the coal blocks) before being used for the saturations to preserve natural conditions. The detailed methodology adopted to prepare the samples is discussed in Ranathunga, Perera, Ranjith and Bui [16].

Table 2. Physical properties of Victorian brown coal and Southern Sydney basin bituminous coal used for the study.

\begin{tabular}{ccc}
\hline Physical Property & Brown Coal [16] & Black Coal [15] \\
\hline Coal density $\left(\mathrm{g} / \mathrm{cm}^{3}\right)$ & $1.04-1.1$ & $1.4-1.9$ \\
Moisture content $(\% \mathrm{wb})^{1}$ & $57-66$ & $1-5$ \\
Fixed carbon $(\% \mathrm{db})^{1}$ & 48 & $60-71$ \\
Ash yield $(\% \mathrm{db})^{1}$ & 1.7 & $6-12$ \\
Volatile matter content $(\% \mathrm{db})^{1}$ & 50.3 & $10-25$ \\
Vitrinite reflectance $(\%)$ & $0.0-0.4^{2}$ & $1.1-1.5^{2}$ \\
\hline
\end{tabular}

${ }^{1}$ wb-wet basis, db-dry basis; ${ }^{2}$ From Silva [24].

\subsection{Samples Preparation for Testing}

The procedures implemented for water and $\mathrm{N}_{2}$ saturations are explained in the following sections.

\subsubsection{Water Saturation}

Three coal samples from each rank were saturated in water for approximately three weeks to allow full water saturation. The samples were placed in vacuum chambers (Figure 1a) and the weight of the coal samples was recorded before placing them into the saturation chamber. The weight was then checked over time for around three weeks until the weight reached a steady state. The samples were then wrapped well with plastic wraps and stored in the fog room for another two weeks to allow an equal distribution of moisture throughout the sample before testing. 


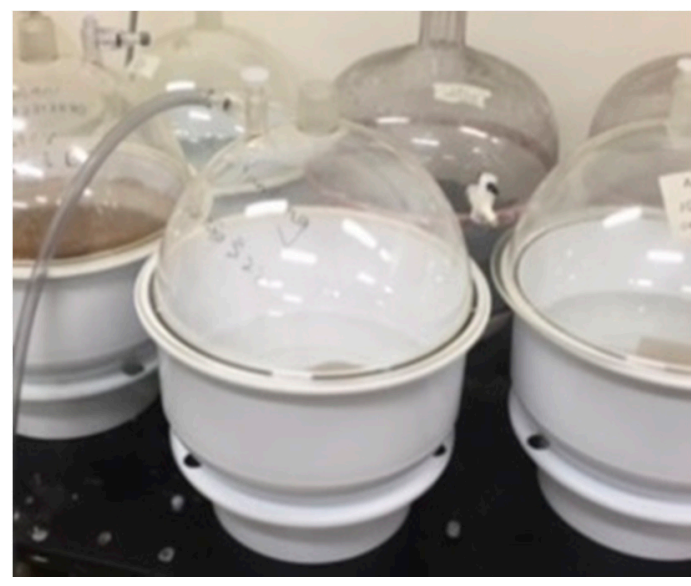

(a)

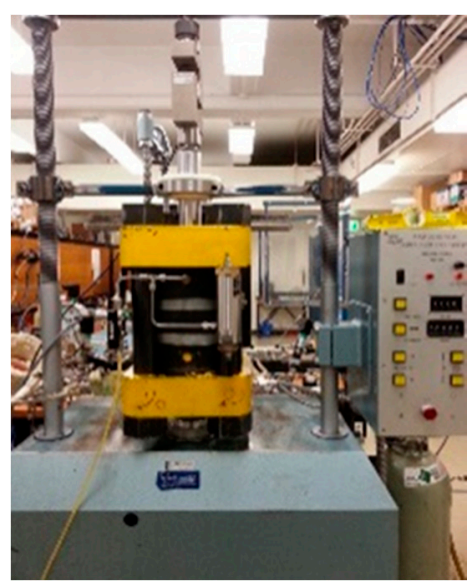

(b)

Figure 1. Coal samples in (a) water saturation chamber and (b) $\mathrm{N}_{2}$ saturation chamber.

\subsection{2. $\mathrm{N}_{2}$ Saturation}

During the study by Perera, Ranjith and Viete [15], the black coal samples were saturated under two different $\mathrm{N}_{2}$ pressures ( 8 and $16 \mathrm{MPa}$ ) using a high pressure tri-axial test rig (see Figure $1 \mathrm{~b}$ ) to compare the observations of $\mathrm{CO}_{2}$ saturated samples. Unlike $\mathrm{CO}_{2}, \mathrm{~N}_{2}$ is a comparatively inert gas, which does not cause any significant coal matrix re-arrangement through chemical interactions with the coal mass $[23,26]$. For this study, brown coal samples were saturated under three different saturation pressures $(2,6$ and $8 \mathrm{MPa})$ using a similar procedure to that reported in Perera, Ranjith and Viete [15]. Further, black coal samples were saturated under two other different saturation pressures (2 and $6 \mathrm{MPa}$ ) additional to those used in the study of Perera, Ranjith and Viete [15] for comparison purposes. Here the samples were saturated under $35^{\circ} \mathrm{C}$ temperature to provide similar conditions to those used for $\mathrm{CO}_{2}$ saturation in Ranathunga, Perera, Ranjith and Bui [16] and Perera, Ranjith and Viete [15]. It should be noted that upon the completion of each saturation, the pressure cell was depressurized gradually at a quite slow rate of around $0.02 \mathrm{MPa} / \mathrm{min}$ to avoid any possible damage to the coal mass caused by the sudden pressure release.

\subsection{Experimental Procedure}

The following sections summarize the experimental methodology adopted for the testing.

\subsubsection{Unconfined Compressive Strength (UCS) Tests}

A series of UCS tests was performed on the coal samples using the Shimadzu compression machine available in the Deep Earth Energy Research Laboratory (DEERL) at Monash University. A displacement rate of $0.1 \mathrm{~mm} / \mathrm{min}$ [27] was applied for the uniaxial compressive tests of the coal samples and the corresponding load and displacement were recorded.

\subsubsection{Acoustic Emission (AE) Tests}

An advanced acoustic emission (AE) system was used to observe the fracture propagation patterns of the tested brown and black coal samples during the UCS testing. Two AE sensors attached at either side of the specimen were used to capture the acoustic counts during the load application. These $\mathrm{AE}$ data were used to characterize the crack propagation stages and to obtain the stress threshold values for each condition. 


\subsubsection{Scanning Electron Microscopy (SEM) Analysis}

High-resolution SEM images were also taken of the coal samples under unsaturated, water-saturated, $\mathrm{N}_{2}$-saturated and $\mathrm{CO}_{2}$-saturated conditions. The scanning was carried out with 4.5 spot size under $15 \mathrm{kV}$ voltage while maintaining a low vacuum mode using the FEI Quanta 3D FEG FIB machine located at the Monash Centre for Electron Microscopy (MCEM), thus providing a fixed resolution of 2 microns for the qualitative analysis of all images. The complete procedure adopted for SEM analysis is detailed in Ranathunga, Perera, Ranjith and Bui [16].

\section{Experimental Results and Discussion}

Axial stress-strains and AE responses were tested for brown and black coal samples under different fluid saturation conditions. The highest UCS values were used to represent the different test conditions for discussion purposes, as the variation of experimental values was minimal. In addition, SEM images were also incorporated to show the micro-structural changes in the coal matrix under different fluid saturations. The following sections discuss and compare how the different coal types behave under the saturation of various fluids.

\subsection{Effect of Coal Rank on Water Saturation Effect on Geomechanical Properties in Coal}

Figure 2 shows the variation of axial stress with axial strain for water-saturated brown and black coal samples. According to Figure 2 and Table 3, brown coal exhibits a UCS value of $2.04 \mathrm{MPa}$ and a Young's modulus value of $35.46 \mathrm{MPa}$ after water saturation, which represent around a $14.64 \%$ reduction of UCS and a 16.21\% reduction of Young's modulus compared to the unsaturated brown coal samples. Black coal exhibits a UCS of $21.01 \mathrm{MPa}$ and Young's modulus of $2.24 \mathrm{GPa}$ after water saturation (refer Table 3), which represents around 36.33\% reduction in UCS and a $39.46 \%$ reduction in Young's modulus compared to the unsaturated black coal samples. Both black and brown coal show a similar behavior for water saturation; there is a considerable reduction in their mechanical properties with water saturation. The major reason for this water saturation-induced strength reduction is the softening of the rock mass bond structure [19] and the ability of moisture inside the rock mass to decrease the surface energy [28]. Furthermore, moisture in a rock mass can cause its toughness to be increased [29], by enhancing the ductile behavior, resulting in a lower Young's modulus.

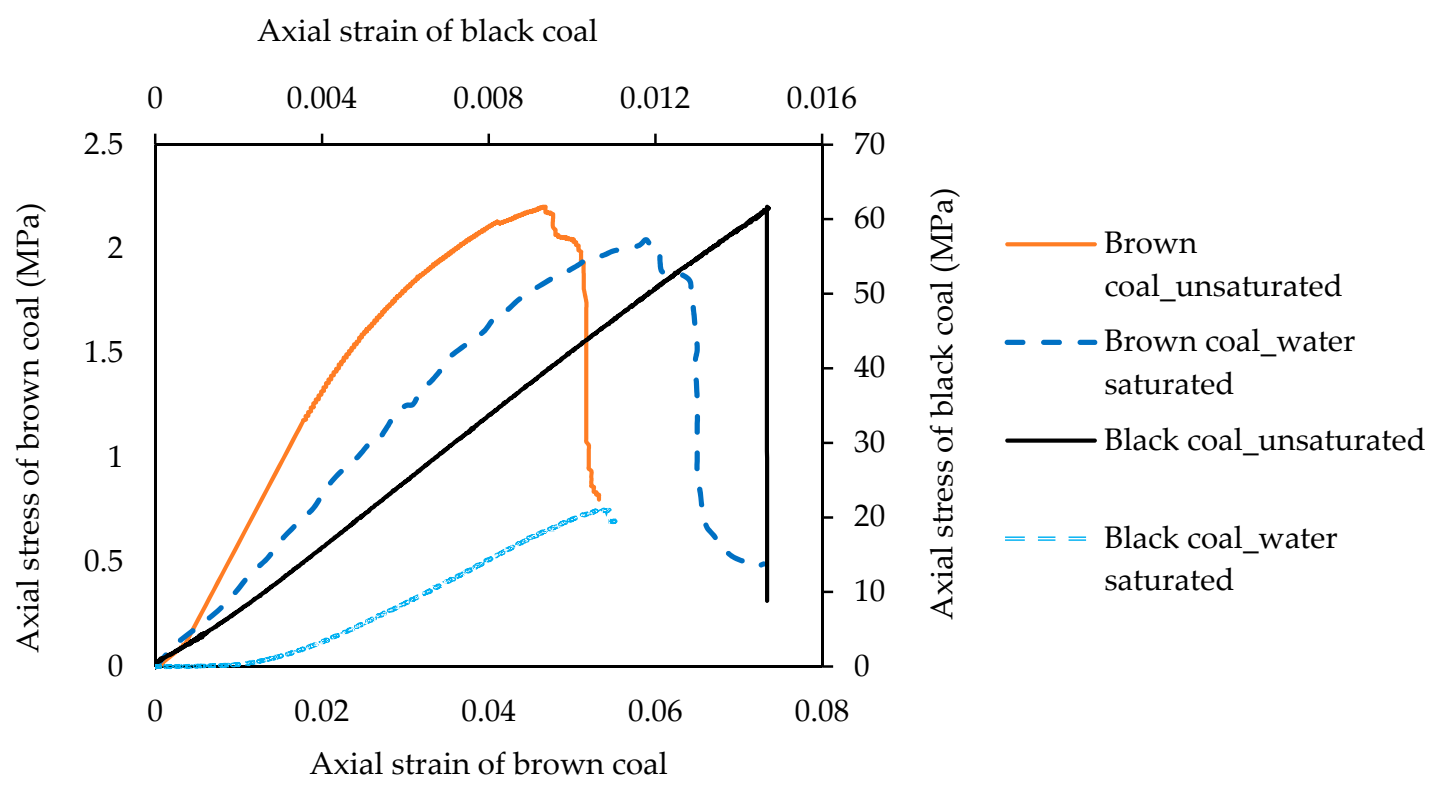

Figure 2. Axial stress vs. axial strain curves for brown coal and black coal during water saturation. 
Table 3. Unconfined compressive strength (UCS) and Young's modulus (E) values obtained under various saturation conditions for brown coal and black coal.

\begin{tabular}{|c|c|c|c|c|c|c|c|c|c|}
\hline \multirow{2}{*}{$\begin{array}{l}\text { Saturation } \\
\text { Fluid }\end{array}$} & \multirow{2}{*}{$\begin{array}{l}\text { Pressure } \\
\text { (MPa) }\end{array}$} & \multicolumn{4}{|c|}{ Brown Coal } & \multicolumn{4}{|c|}{ Black Coal } \\
\hline & & $\begin{array}{l}\text { UCS } \\
(\mathrm{MPa})\end{array}$ & $\begin{array}{c}\Delta \text { UCS } \\
(\%)^{3}\end{array}$ & $\begin{array}{c}\mathrm{E} \\
(\mathrm{MPa})\end{array}$ & $\Delta \mathrm{E}(\%)^{3}$ & $\begin{array}{c}\text { UCS } \\
(\mathrm{MPa})\end{array}$ & $\begin{array}{c}\Delta \mathrm{UCS} \\
(\%)^{3}\end{array}$ & E (GPa) & $\Delta \mathrm{E}(\%)^{3}$ \\
\hline \multirow{3}{*}{ Unsaturated } & - & $2.39^{1}$ & - & $42.32^{1}$ & - & $31.01^{2}$ & - & $3.52^{2}$ & - \\
\hline & - & $2.34^{1}$ & - & $39.32^{1}$ & - & $33.00^{2}$ & - & $3.70^{2}$ & - \\
\hline & - & $2.36^{1}$ & - & $42.16^{1}$ & - & - & - & - & - \\
\hline \multirow{3}{*}{ Water } & - & 2.07 & -14.64 & 35.46 & -16.21 & 21.01 & -36.33 & 2.24 & -39.46 \\
\hline & - & 2.01 & & 35.17 & & 20.89 & & 2.14 & \\
\hline & - & 2.05 & & 35.28 & & 20.94 & & 2.20 & \\
\hline \multirow{8}{*}{$\mathrm{N}_{2}$} & 2 & 2.43 & 1.58 & 42.52 & 0.47 & 33.39 & 1.18 & 3.71 & 0.27 \\
\hline & 2 & 2.39 & & 41.97 & & 32.17 & & 3.54 & \\
\hline & 6 & 2.51 & 5.05 & 43.08 & 1.80 & 33.76 & 2.30 & 3.76 & 1.62 \\
\hline & 6 & 2.48 & & 43.01 & & 32.89 & & 3.64 & \\
\hline & 8 & 2.57 & 7.56 & 44.28 & 4.63 & $34.01^{2}$ & 3.06 & $3.80^{2}$ & 2.70 \\
\hline & 8 & 2.54 & & 44.16 & & $33.20^{2}$ & & $3.71^{2}$ & \\
\hline & 16 & - & - & - & - & $35.11^{2}$ & 6.39 & $3.91^{2}$ & 5.68 \\
\hline & 16 & & & & & $33.30^{2}$ & & $3.71^{2}$ & \\
\hline
\end{tabular}

${ }^{1}$ From Ranathunga, Perera, Ranjith and Bui [16]; ${ }^{2}$ From Perera, Ranjith and Viete [15]; ${ }^{3}$ The sample with the highest UCS value was taken to calculate the UCS and E variations.

Interestingly, compared to brown coal, black coal has around 2.5 times higher reduction in both UCS and Young's modulus. This significant mechanical property weakening in black coal has also been observed by Vishal, Ranjith and Singh [17] for Indian black coal (around 25.5\% UCS reduction and $37.8 \%$ Young's modulus reduction upon water saturation). This is possibly due to the fact that black coal has more fractures and a well-developed cleat system that allow more intake of moisture into the coal mass. The water molecules can dissolve in the material and can be drawn to the tips of the fractures, causing more stress towards the fracture tips, resulting in their expansion [28]. Hence, black coal exhibits a higher strength reduction than brown coal, which has fewer fractures and under-developed cleats. These observations can be further confirmed by comparing the SEM images of unsaturated and water-saturated coal samples (see Table 4). Here, compared to unsaturated samples, both brown and black coals show altered micro structures after water saturation and these alterations are clearly greater in black coal.

Figure 3 compares the AE counts with axial stress for brown and black coals with and without water saturation. As shown in Figure 3, the unsaturated samples exhibit clear fracture propagation behavior with all the three main stages under load application compared to the water-saturated samples. A crack closure (CC) region can first be observed without any strain energy release. A stable crack propagation (SC) region can then be witnessed, at which crack propagation is initiated (crack initiation stress- $\left.\sigma_{\mathrm{ci}}\right)$, releasing strain energy linearly without damaging the sample. Unstable crack propagation (UC) can finally be seen, which starts at the crack damage point $\left(\sigma_{\mathrm{cd}}\right)$ and progresses until the sample fails (UCS) with an exponential increment in strain energy released.

However, in water-saturated coal samples, these three stages are not clearly visible. Brown coal (see Figure 3a) portrays only crack closure and then sample failure without any stable or unstable crack propagation. As discussed previously, moisture intake into the rock mass causes the fracture tips of the specimen to be weakened, which may result in failure without any crack propagation. However, stable and unstable crack propagation can be observed for water-saturated black coal before it undergoes failure. The reason may be the softer and weaker properties of brown coal compared to black coal that cause it to fail rapidly, with water saturation creating a softening effect. 
Table 4. Appearance of the brown and black coal samples under different fluid saturations before and after failure.

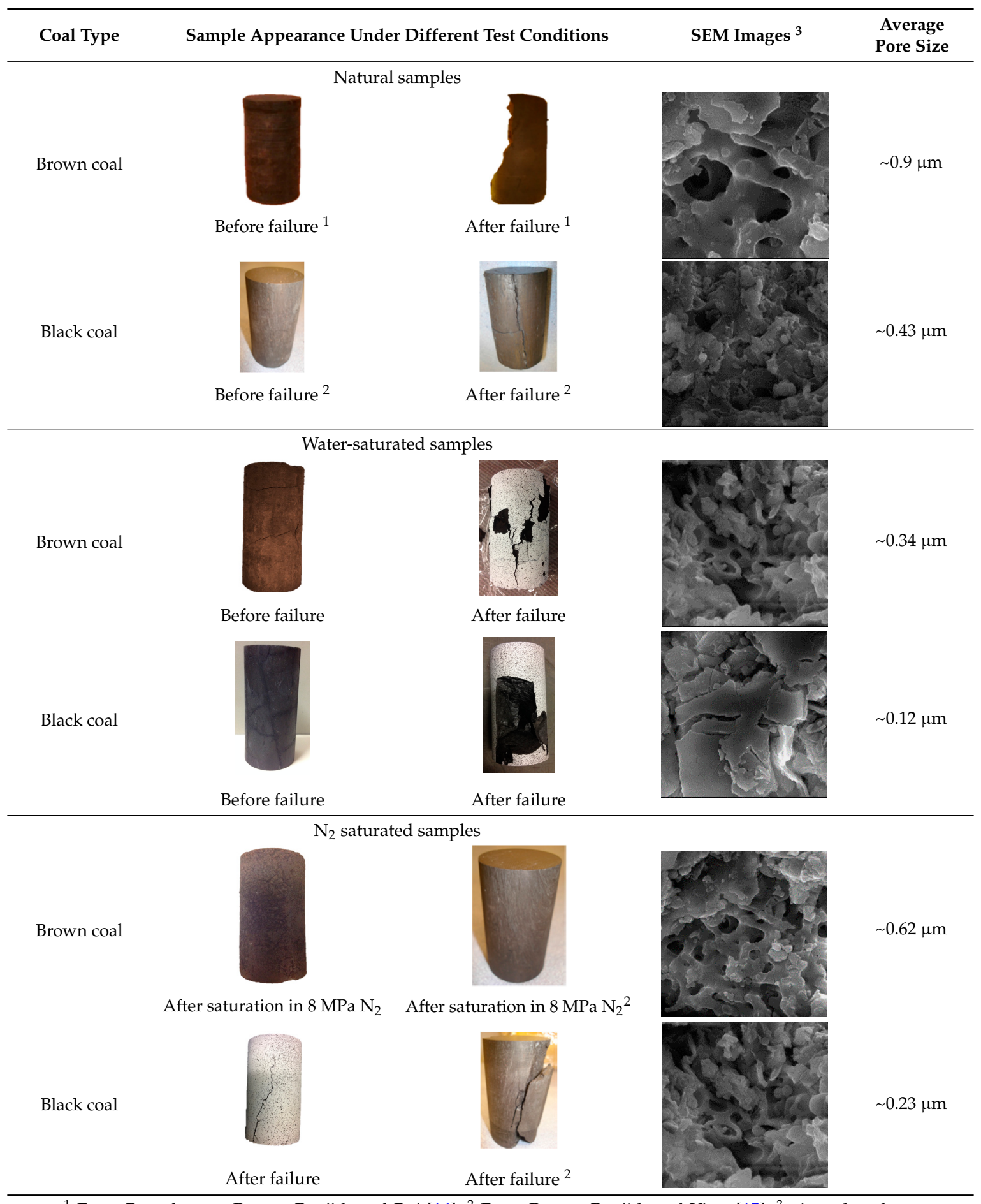

${ }^{1}$ From Ranathunga, Perera, Ranjith and Bui [16]; ${ }^{2}$ From Perera, Ranjith and Viete [15]; ${ }^{3}$ viewed under a magnification of $17,500 \times$, a working distance of $10 \mathrm{~mm}$ and a voltage of $15 \mathrm{kV}$. 


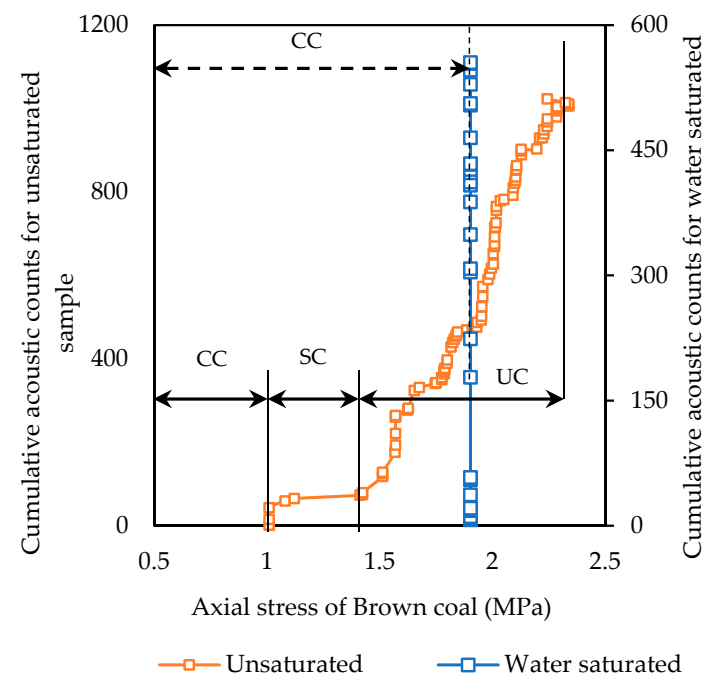

(a)

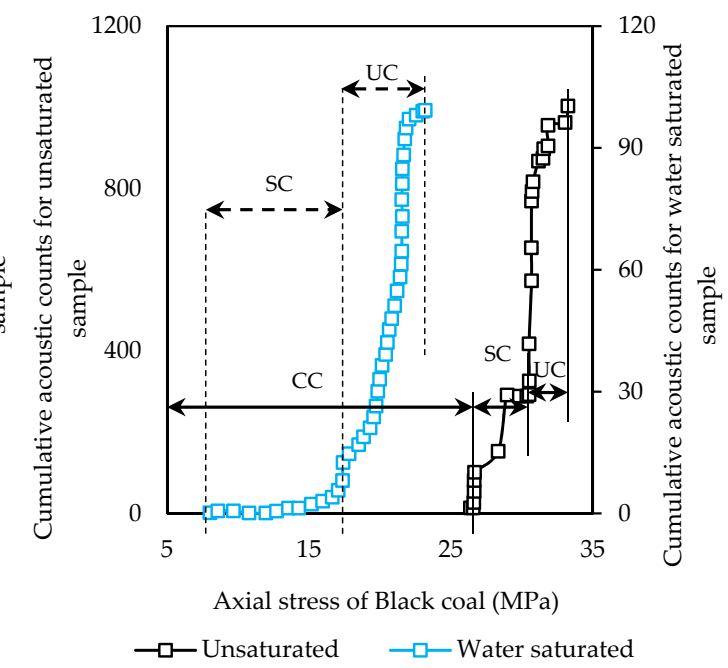

(b)

Figure 3. Cumulative acoustic counts versus axial stress for unsaturated and water saturated (a) brown coal and (b) black coal samples (Here CC-Crack closure, SC-Stable crack propagation and UC-Unstable crack propagation).

After water saturation, the brown coal samples were observed to have a very soft and bulgy appearance compared to the water-saturated black coal samples. Further, the water-saturated brown coal had a bulging failure and black coal exhibited a failure along the major and minor cleats (see Table 4). This is possibly because, due to the well-developed cleat system in high rank black coal compared to brown coal, water molecules have more possibility to move through these cleat systems and weaken the coal mass along them in black coal. In the case of brown coal, which has only a poorly developed cleat system, water molecules slowly diffuse into the whole rock matrix, weakening the coal matrix. Black coal shows more rapid crack propagation after water saturation, probably because the weaker cleat system allows fractures to easily propagate through the system. For example, the crack initiation stress for the unsaturated sample is $26.7 \mathrm{MPa}$ while it is $6.74 \mathrm{MPa}$ for the water-saturated sample. Furthermore, the crack damage occurred at $30.5 \mathrm{MPa}$ for the unsaturated sample and at 17.15 MPa for the water-saturated sample (see Figure $3 \mathrm{~b}$ ). In summary, water saturation causes a strength reduction in any coal regardless of rank. However, high rank coal exhibits a greater strength reduction than low rank coal with water saturation, mainly due to the mature fracture network, which easily attracts water molecules. In addition, water saturation causes a direct failure in low rank brown coal (without fracture propagation) compared to high rank coal, which exhibits more rapid fracture propagation after water saturation compared to its dry condition.

\subsection{Rank Effect on $\mathrm{N}_{2}$ Saturation-Created Geomechanical Alterations in Coal}

The effects of $\mathrm{N}_{2}$ saturation on brown and black coal's mechanical properties were then investigated and the results are shown in Figure 4 and Table 3. According to Figure 4, unlike in water saturation, $\mathrm{N}_{2}$ saturation causes a slight increment in coal strength for both brown and black coal, and the strength gain is increased by increasing $\mathrm{N}_{2}$ saturation pressure. The reason may be the ability of $\mathrm{N}_{2}$ to push the existing moisture from the coal mass. This was evident by the calculated weight variation in the $\mathrm{N}_{2}$-saturated samples, which was reduced by around $5 \%$ to $19 \%$ during the saturation period. As mentioned in the previous section, moisture in a coal mass causes its structure to be weakened, and the removal of moisture from the rock mass should therefore cause a strength gain. 


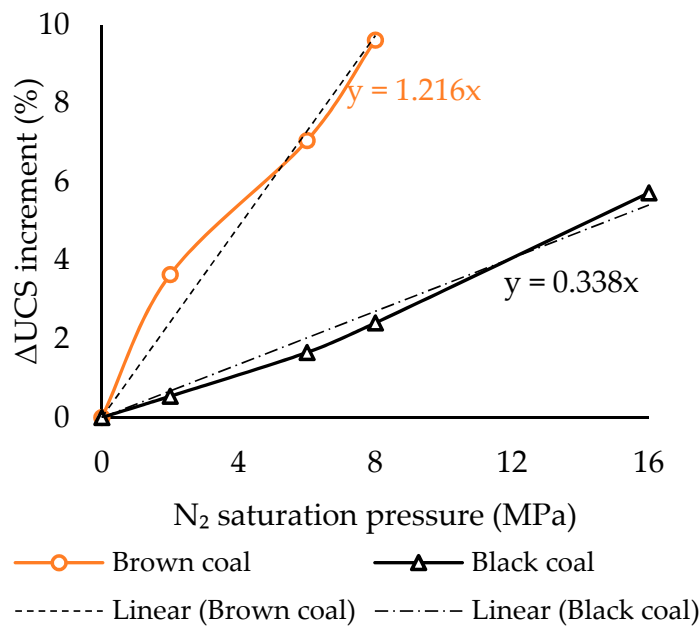

(a)

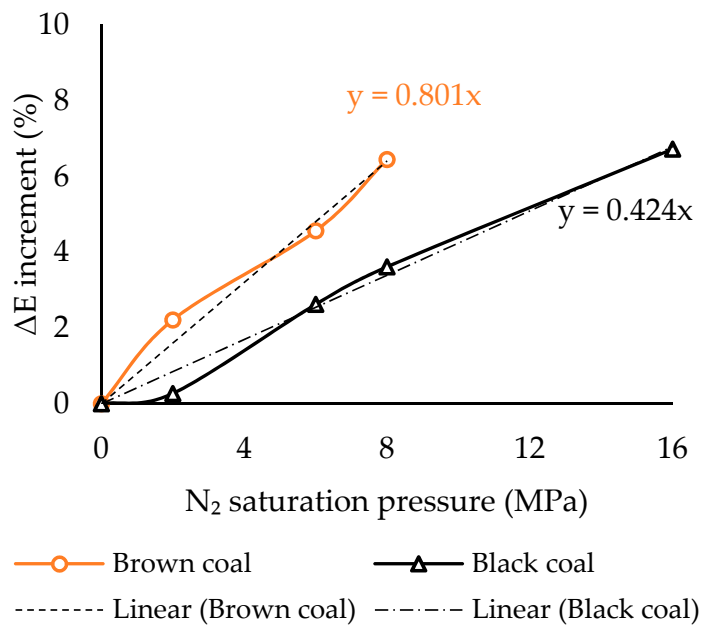

(b)

Figure 4. (a) Compressive strength (UCS) and (b) Young's modulus (E) increment during $\mathrm{N}_{2}$ saturation for brown and black coal.

Further, according to Table 3, the Young's modulus of both brown coal and black coal slightly increase after $\mathrm{N}_{2}$ saturation, and this is also related to the moisture removing potential of the $\mathrm{N}_{2}$ molecules. As described earlier, the existence of water causes the ductile properties of the coal mass to improve. Therefore, the removal of water should improve the brittle behavior, which is proven by the observed Young's modulus increment in both brown and black coal after $\mathrm{N}_{2}$ saturation. Further, at higher $\mathrm{N}_{2}$ saturation pressures, the amount of $\mathrm{N}_{2}$ molecules that enter the coal mass is higher. Therefore, the removal of moisture from the sample is also higher, which causes greater strength gains. Apart from this moisture release, $\mathrm{N}_{2}$ injection may also cause the release of some adsorbed phase gases such as methane and $\mathrm{CO}_{2}$ from the coal matrix [22]. The adsorption of any of these coal seam gases $\left(\mathrm{CH}_{4}, \mathrm{CO}_{2}\right)$ causes the coal matrix to swell and injecting $\mathrm{N}_{2}$ causes these swelled areas to recover to some extent. Coal swelling causes its strength to be reduced, and therefore even the partial recovery of swelling by injecting $\mathrm{N}_{2}$ should contribute to the enhancement of the strength of the coal mass.

The aim of this study is to identify the effect of coal rank on these coal mass mechanical property alterations under various fluid injections. According to Figure 4, the $\mathrm{N}_{2}$ saturation-created strength gain in brown coal samples is greater than the strength gain in black coal after $\mathrm{N}_{2}$ saturation (see Figure 4). For example, the UCS shows a 1.216 positive gradient for brown coal and a 0.338 positive gradient for black coal with $\mathrm{N}_{2}$ saturation pressure, while Young's modulus shows a 0.801 and 0.424 positive gradient with $\mathrm{N}_{2}$ saturation pressure for brown and black coals, respectively. This is mainly related to the available moisture in black and brown coals. According to Table 2, the moisture content in brown coal (average 62\%) is much higher than in black coal (average 3\%). The amount of moisture removed from the coal mass by introducing $\mathrm{N}_{2}$ is therefore higher in brown coal, and this should cause a greater strength gain in brown coal than in black coal. According to the SEM images of $8 \mathrm{MPa}$ $\mathrm{N}_{2}$ saturated brown and black coal samples (see Table 4), brown coal exhibits a clearer micro pore structure compared to black coal after water saturation, probably due to the water removed from the pore space. The SEM image of $\mathrm{N}_{2}$ saturated black coal shows some open pore spaces compared to the unsaturated black coal, possibly due to the moisture removed from the coal matrix. This proves the strength gains observed for $\mathrm{N}_{2}$ saturated black and brown coal.

The $\mathrm{AE}$ analysis data for $\mathrm{N}_{2}$ saturation, unlike water saturation, shows considerable delays in crack initiation to crack damage (stable crack propagation) for both high and low rank coals (see Table 4). For instance, $8 \mathrm{MPa} \mathrm{N}_{2}$ saturation caused the stable crack propagation in brown coal to increase from around 0.41 MPa to 0.6 MPa and in black coal from around 2.68 MPa to 3.8 MPa. This may be due to the lower water content in the $\mathrm{N}_{2}$ saturated sample. An increase of surface energy 
may take place with the water removal from the $\mathrm{N}_{2}$ saturated coal samples, eventually causing a delay in crack propagation. Interestingly, a comparison of the stress threshold values of $\mathrm{N}_{2}$ saturated brown and black coal shows that both display very similar behavior, as shown by the UCS and Young's modulus results, which show an increment with increasing $\mathrm{N}_{2}$ saturation pressure, and a greater increment for brown coal compared to black coal. The previously mentioned moisture removal rate is the reason for this observation, further confirming the ability of $\mathrm{N}_{2}$ to cause strength gain in the coal mass. Hence, it can be concluded that $\mathrm{N}_{2}$ has the ability to slightly enhance the strength properties of coal and this ability is higher for low rank coal.

\subsection{How Significant is Water and $\mathrm{N}_{2}$ Saturation on Coal Strength Compared to That of $\mathrm{CO}_{2}$}

Coal generally has a mixture of pore fluid, composed of water, $\mathrm{N}_{2}, \mathrm{CO}_{2}$ and $\mathrm{CH}_{4}$ and their composition can be changed with various applications such as $\mathrm{CO}_{2}$ sequestration and $\mathrm{N}_{2}$ injection for ECBM recovery. It is therefore necessary to have comprehensive knowledge of the relative effect created by each component. Particularly in the case of $\mathrm{CO}_{2}$ sequestration, knowledge of the effects of other fluid saturations compared to $\mathrm{CO}_{2}$ saturation is necessary to have an overall idea of coal mass strength in this process. In addition, such a comparative study is essential for various ranked coals to determine the effects of these processes on coal seam. In this respect, Perera et al. [24] conducted a series of strength tests to compare the influence of water and $\mathrm{N}_{2}$ saturation with that of $\mathrm{CO}_{2}$ saturation. However, they conducted this series of strength tests on coal samples saturated under only very low pressure conditions (up to $3 \mathrm{MPa}$ ). These are far from the real situation in the field, in which quite high injection pressures of $\mathrm{CO}_{2}$ and $\mathrm{N}_{2}$ are used and the natural water is under very high pore fluid pressures. Therefore, the conduct of a comparative study with greater and more realistic saturation pressures is necessary to understand field conditions, while also incorporating other possible influences such as the $\mathrm{CO}_{2}$ phase effect. Further, a study of different ranked coal is necessary to identify how these influences vary from seam to seam or with coal maturity. This section therefore compares the findings of the present study with those of previous studies on the effect of $\mathrm{CO}_{2}$ saturation on low ranked brown coal [16] and high-ranked black coal [15].

\subsubsection{Comparison of Variation of Coal's Mechanical Properties}

Figure 5 compares the UCS and Young's modulus of $\mathrm{CO}_{2}$ and $\mathrm{N}_{2}$ saturated brown and black coals. According to this figure, there is a clear strength reduction with $\mathrm{CO}_{2}$ adsorption and in contrast a strength gain with $\mathrm{N}_{2}$ adsorption regardless of rank, and both types of strength property alterations are enhanced with increasing saturation pressure. However, when comparing brown and black coals, greater reductions in UCS and Young's modulus with $\mathrm{CO}_{2}$ saturation in black coal can be seen, due to its well-defined cleat system. In contrast, a lower strength gain under $\mathrm{N}_{2}$ saturation in black coal can be seen due to the previously described lower moisture content of high rank coal. The influence of $\mathrm{N}_{2}$ and $\mathrm{CO}_{2}$ saturation on coal mechanical properties varies greatly under high saturation pressure conditions. For example, the $\mathrm{CO}_{2}$ adsorption-induced strength reduction in both black and brown coals is significantly enhanced after around $8 \mathrm{MPa}$, with the phase variation of $\mathrm{CO}_{2}$ from sub- to more chemically reactive super-critical conditions (see Figure 5). This change cannot be seen in $\mathrm{N}_{2}$ saturation with increasing pressure (a more linear variation with saturation pressure can be seen), because the $\mathrm{N}_{2}$ phase does not change under such conditions (for $\mathrm{N}_{2}$ the critical temperature is $-146.8^{\circ} \mathrm{C}$ and the critical pressure is $3.39 \mathrm{MPa}$ ) [23]. This is particularly important for field projects, in which coal seams are under very high saturation pressures and temperatures, and completely different responses to $\mathrm{CO}_{2}$ and $\mathrm{N}_{2}$ injections into the seam should be expected.

Now if the water saturation and $\mathrm{CO}_{2}$ saturation effect on coal strength are compared, quite similar behavior can be observed, as both cause the coal mechanical properties to be weaken, with black coal being subjected to more weakening than brown coal due to its cleat system. However, how the water saturation effect varies with saturation pressure could not be tested in the present study. This would give important information on the pressure effect on water softening and warrants future research. 


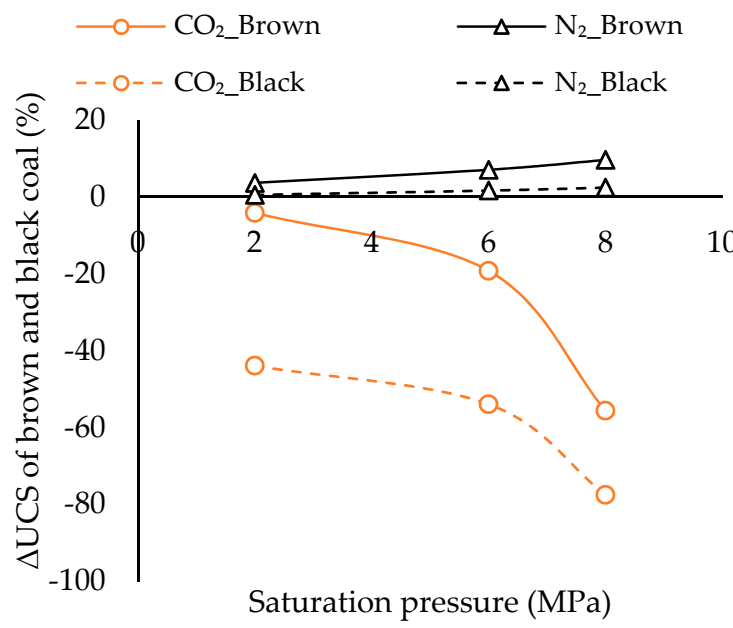

(a)
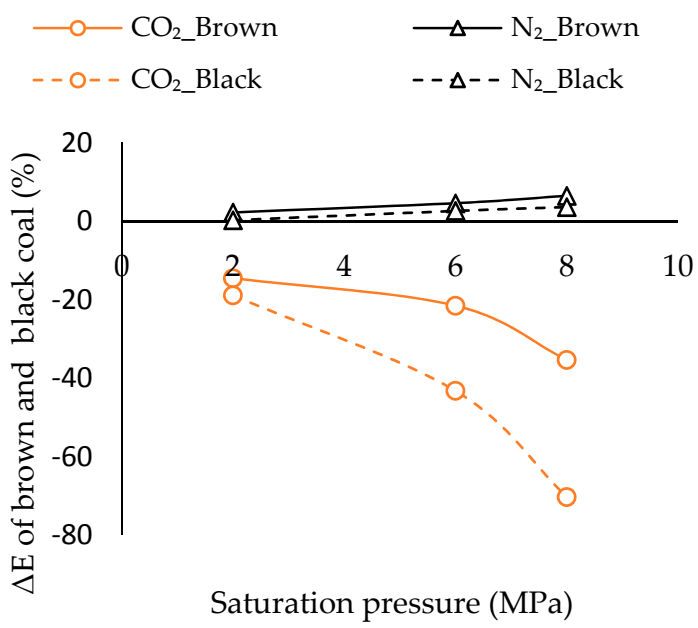

(b)

Figure 5. Comparison of (a) UCS and (b) Young's modulus variation with $\mathrm{CO}_{2}[15,16]$ and $\mathrm{N}_{2}$ saturation of brown coal and black coal.

\subsubsection{Comparison of Fracture Propagation}

Figure 6 shows the variation of normalized stress threshold values and Table 5 displays the respective stress threshold values for brown and black coal saturated with $\mathrm{CO}_{2}$ [15] and $\mathrm{N}_{2}$ [16]. Here, the values have been normalized by dividing each stress value by the respective stress threshold value under unsaturated condition. According to the AE data, (see Figure 6 and Table 5), unlike in $\mathrm{N}_{2}$ saturation, $\mathrm{CO}_{2}$ saturation causes quicker crack initiation and crack damage in both high and low rank coals, probably due to the reduced surface energy with $\mathrm{CO}_{2}$ adsorption [24]. For instance, at around $4 \mathrm{MPa} \mathrm{CO}$ saturation, there is around $0.74 \mathrm{MPa}$ normalized crack initiation stress for brown coal and around 0.51 MPa crack initiation stress for black coal (around 4.5 MPa saturation pressure in black coal). Further, when comparing the stress threshold values in $\mathrm{CO}_{2}$ saturated brown and black coal, both display very similar behavior in terms of UCS and Young's modulus (see Table 5), and a reducing stress threshold trend with increasing $\mathrm{CO}_{2}$ saturation pressure, the reduction being greater for black coal than brown coal (see Figure 6). The well-developed cleat system in black coal compared to brown coal might be the reason for this observation. Further, for super-critical $\mathrm{CO}_{2}$ saturations, black coal exhibits crack propagation without any crack initiation (see Figure 6a), probably due to the enhanced ductile behavior of samples under super-critical $\mathrm{CO}_{2}$ adsorption, which causes higher plasticization in the coal mass. In addition, crack propagation in $\mathrm{N}_{2}$ saturation also displays a similar behavior with the variation of strength parameters, which shows an increment in stress threshold with increasing $\mathrm{N}_{2}$ saturation pressure, the increment being greater for brown coal due to greater moisture removal. Based on these crack propagation changes which occur with $\mathrm{CO}_{2}$ and $\mathrm{N}_{2}$ saturations, the use of $\mathrm{N}_{2}$ to recover the $\mathrm{CO}_{2}$ adsorption-induced coal matrix alteration appears to be an effective option.

In relation to crack propagation in water- and $\mathrm{CO}_{2}$-saturated samples, both show more rapid crack propagation (see Table 5) compared to $\mathrm{N}_{2}$ saturation, and particularly in water-saturated sampled, crack initiation is not even visible (see Figure 6 and Table 5). In the case of $\mathrm{CO}_{2}$ saturation, $\mathrm{CO}_{2}$ adsorption-induced coal matrix swelling causes a strain layer to be generated between the adsorbed $\mathrm{CO}_{2}$ and the fracture/cleat face $[9,11]$. Hence, with lower axial load applications, this weak layer possibly starts to break, causing rapid crack propagation [30]. During water saturation, the water $\left(\mathrm{H}_{2} \mathrm{O}\right)$ molecules react with mineral/macerals and also create hydrogen bonds with the existing moisture in the coal mass [17], which results in structural rearrangements. Further, an expansion of fracture tips may occur due to the water molecule-induced internal stress increment [24], therefore initiating an early failure without any visible crack propagation. 
Sub-critical region

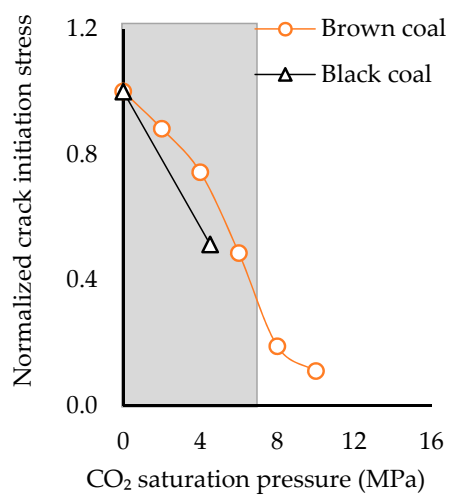

(a)

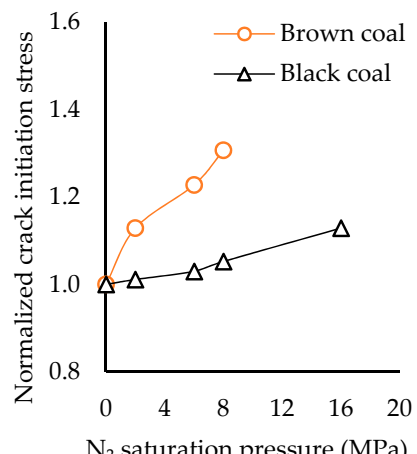

(d)

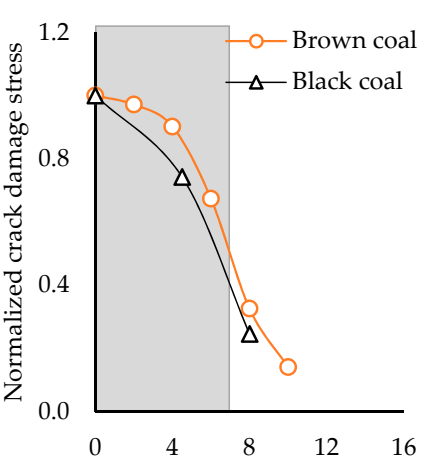

$\mathrm{CO}_{2}$ saturation pressure $(\mathrm{MPa})$

(b)

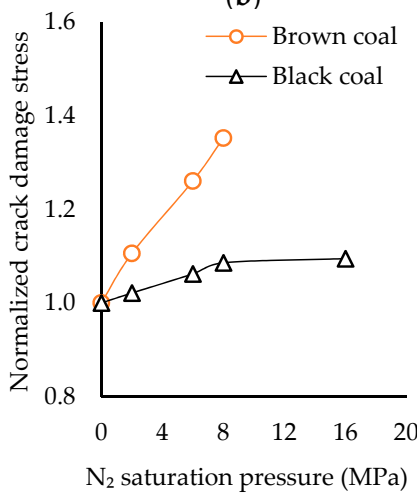

(e)

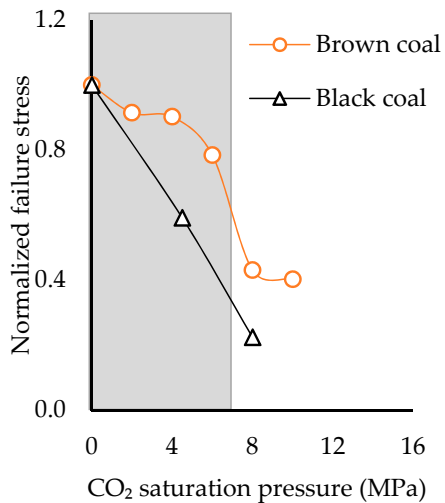

(c)

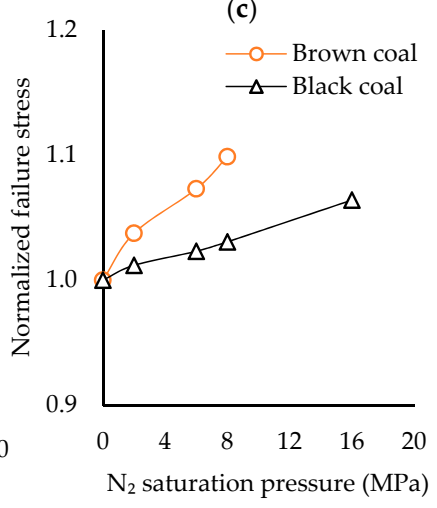

$(\mathbf{f})$

Figure 6. Variation of normalized stress threshold values: (a) crack initiation stress, (b) crack damage stress, and (c) failure stress during different $\mathrm{CO}_{2}$ saturations for brown coal and black coal; and (d) crack initiation stress, (e) crack damage stress, and (f) failure stress during different $\mathrm{N}_{2}$ saturations for brown coal and black coal (here the stress threshold values were normalized by dividing by the respective stress threshold value for unsaturated sample).

Table 5. Stress threshold values obtained under various saturation conditions for brown coal and black coal.

\begin{tabular}{|c|c|c|c|c|c|c|c|}
\hline \multirow[b]{2}{*}{ Saturation Fluid } & \multirow{2}{*}{$\begin{array}{c}\text { Saturation } \\
\text { Pressure (MPa) }\end{array}$} & \multicolumn{3}{|c|}{ Brown Coal } & \multicolumn{3}{|c|}{ Black Coal } \\
\hline & & $\begin{array}{l}\text { Crack Initiation } \\
\text { Stress }\left(\sigma_{\mathrm{ci}}, \mathrm{MPa}\right)\end{array}$ & $\begin{array}{c}\text { Crack Damage } \\
\text { Stress }\left(\sigma_{\mathrm{cd}}, \mathrm{MPa}\right)\end{array}$ & $\begin{array}{l}\mathrm{UCS} \\
\text { (MPa) }\end{array}$ & $\begin{array}{l}\text { Crack Initiation } \\
\text { Stress }\left(\sigma_{c i}, \text { MPa) }\right.\end{array}$ & $\begin{array}{c}\text { Crack Damage } \\
\text { Stress }\left(\sigma_{\mathrm{cd}}, \mathrm{MPa}\right)\end{array}$ & $\begin{array}{l}\text { UCS } \\
\text { (MPa) }\end{array}$ \\
\hline Unsaturated & - & $1.01^{1}$ & $1.42^{1}$ & $2.39^{1}$ & $26.70^{2}$ & $30.50^{2}$ & $33.00^{2}$ \\
\hline Water & - & - & - & 2.06 & - & 17.15 & 20.94 \\
\hline \multirow{4}{*}{$\mathrm{N}_{2}$} & 2 & 1.14 & 1.57 & 2.43 & 27.10 & 29.38 & 33.39 \\
\hline & 6 & 1.24 & 1.79 & 2.51 & 27.53 & 30.43 & 33.76 \\
\hline & 8 & 1.32 & 1.92 & 2.57 & $28.10^{2}$ & $31.90^{2}$ & $34.01^{2}$ \\
\hline & 16 & - & - & - & $30.14^{2}$ & $32.16^{2}$ & $35.11^{2}$ \\
\hline
\end{tabular}

${ }^{1}$ From Ranathunga, Perera, Ranjith and Bui [16]; ${ }^{2}$ From Perera, Ranjith and Viete [15].

\section{Conclusions and Suggestions for Future Research}

\subsection{Conclusions Drawn from the Present Study}

The influence of coal rank on various fluid saturation-induced coal mechanical properties changes was studied using low rank (Australian brown coal) and high rank (Australian black coal) coal samples. The following conclusions can be drawn: 
- Water saturation causes a significant strength reduction in coal regardless of rank, because the moisture penetrating into the coal mass causes its fractures to expand, decreasing the surface energy of the coal mass, and eventually causing the strength to be reduced.

- This strength reduction is enhanced with increasing coal rank due to the well-developed cleats in mature coal which offer more loci for moisture to stay in the coal mass.

- The enhanced ductile nature of coal upon water adsorption delays crack initiation, regardless of rank. It is therefore necessary to have a lot of low injection pressure for coal seams with a greater degree of water saturation in terms of safety.

- In contrast to water saturation, $\mathrm{N}_{2}$ saturation slightly enhances coal strength, regardless of rank, and this increment increases with increasing $\mathrm{N}_{2}$ saturation pressures. This is possibly due to the ability of $\mathrm{N}_{2}$ to partially recover the coal seam gas (methane, $\mathrm{CO}_{2}$ ) adsorbed swelled areas and push out the adsorbed water from the coal mass.

- $\quad \mathrm{N}_{2}$ saturation significantly slows crack initiation and propagation in coal regardless of rank. This is a favorable feature in terms of long-term stability in coal seams and can be used to strengthen weak seams after $\mathrm{CO}_{2}$ injection.

- The strength gain created by $\mathrm{N}_{2}$ saturation reduces with increasing rank, probably due to the lower level of moisture stored in high rank coal.

- The variation of mechanical properties of coal upon $\mathrm{CO}_{2}$ and $\mathrm{N}_{2}$ saturations shows quite different responses to increasing saturation pressure, as the $\mathrm{CO}_{2}$ phase condition may change from sub- to super-critical under greater pressures. In contrast, $\mathrm{N}_{2}$ does not undergo such phase change with increasing pressure, due to its much lower critical conditions.

- The present study was conducted under $35^{\circ} \mathrm{C}$ temperature $\left(\mathrm{N}_{2}\right.$ saturation) up to $8 \mathrm{MPa}$ saturation pressure, which represents a pore pressure condition of an approximately $800 \mathrm{~m}$ deep coal seam [31]. As the study was conducted in an unconfined environment, the observed strength variations are expected to be lower in a confined environment under field conditions, because the confinement causes greater effective stress in the field, leading to a shrunken pore structure in coal seams with reduced gas flow performance through them.

\subsection{Suggestions for Furture Research}

- Methane is one of the major components in coal seam gas that plays an important role in the overall mechanical response of the coal mass. Hence, to understand the overall influence of coal seam gas on coal's mechanical properties, future research is needed on methane saturation under various pressures for different rank coals.

- It is recommended to conduct further research on coal mass mechanical behavior under confinements for different saturation conditions to represent the real case scenarios existing in the field, where the coal mass has been exposed to lithostatic pressure conditions.

- The water saturation effect of the present study was conducted under atmospheric pressure conditions due to the unavailability of the necessary laboratory facilities. However, it is essential to investigate the water saturation effect under different pressure conditions, so that it can be clearly compared with the different pressure effects of $\mathrm{N}_{2}$ and $\mathrm{CO}_{2}$. This is a future research option.

- As found in the present study, coal mass mechanical behavior under various saturations varies with different coal types. However, the results of this study need to be generalized by testing various ranked coal samples taken from various coal basins around the world. Future experimentation is therefore recommended using a wider range of coal specimens taken from different basins in the world with diverse cleat structures and mineral compositions, in order to obtain better insight into the observed strength variations. 
Author Contributions: Ashani Savinda Ranathunga performed the experiments, analyzed the data, and prepared the draft manuscript. Mandadige Samintha Anne Perera mentored the experimental program and reviewed the draft. Ranjith Pathegama Gamage reviewed the final paper and made important suggestions and recommendations for paper revision.

Conflicts of Interest: The authors declare no conflict of interest.

\section{Abbreviations}

The following abbreviations are used in this manuscript:

$\begin{array}{ll}\mathrm{AE} & \text { Acoustic emission } \\ \mathrm{CC} & \text { Crack closure } \\ \mathrm{CH}_{4} & \text { Methane } \\ \mathrm{CO}_{2} & \text { Carbon dioxide } \\ \mathrm{db} & \text { Dry basis } \\ \mathrm{E} & \text { Young's modulus } \\ \mathrm{ECBM} & \text { Enhanced coal bed methane recovery } \\ \mathrm{MCEM} & \text { Monash Center of Electron Microscopy } \\ \mathrm{N}_{2} & \text { Nitrogen } \\ \mathrm{SC} & \text { Stable crack propagation } \\ \mathrm{SEM} & \text { Scanning electron microscopy } \\ \mathrm{UC} & \text { Unstable crack propagation } \\ \mathrm{UCS} & \text { Unconfined compressive strength } \\ \mathrm{wb} & \text { Wet basis } \\ \sigma_{\mathrm{cd}} & \text { Crack damage stress } \\ \sigma_{\mathrm{ci}} & \text { Crack initiation stress }\end{array}$

\section{References}

1. Perera, M.S.A.; Ranjith, P.G. Carbon dioxide sequestration effects on coal's hydro-mechanical properties: A review. Int. J. Energ. Res. 2012, 36, 1015-1031. [CrossRef]

2. Ranathunga, A.S.; Perera, M.S.A.; Ranjith, P.G. Deep coal seams as a greener energy source: A review. J. Geophys. Eng. 2014, 11, 063001. [CrossRef]

3. Vishal, V.; Singh, T.N. A laboratory investigation of permeability of coal to supercritical $\mathrm{CO}_{2}$. Geotech. Geol. Eng. 2015, 33, 1009-1016. [CrossRef]

4. Xie, J.; Gao, M.; Yu, B.; Zhang, R.; Jin, W. Coal permeability model on the effect of gas extraction within effective influence zone. Geomech. Geophys. Geo-Energy Geo-Resources 2015, 1, 15-27. [CrossRef]

5. Gale, J. Geological storage of $\mathrm{CO}_{2}$ : What do we know, where are the gaps and what more needs to be done? Energy 2004, 29, 1329-1338. [CrossRef]

6. Zhang, Y.; Gong, B.; Li, J.; Li, H. Discrete fracture modeling of 3D heterogeneous enhanced coalbed methane recovery with prismatic meshing. Energies 2015, 8, 6153-6176. [CrossRef]

7. Hu, G.; Xu, J.; Zhang, F.; Zhao, C.; Qin, W.; Zhu, Y. Coal and coalbed methane co-extraction technology based on the ground movement in the yangquan coalfield, China. Energies 2015, 8, 6881-6897. [CrossRef]

8. Aziz, N.I.; Ming-Li, W. The effect of sorbed gas on the strength of coal - an experimental study. Geotech. Geol. Eng. 1999, 17, 387-402. [CrossRef]

9. Jasinge, D. An investigation of the effect of carbon dioxide sequestration on the behaviour of brown coal. Ph.D. Thesis, Monash University, Melbourne, Australia, 2010.

10. Viete, D.R.; Ranjith, P.G. The effect of $\mathrm{CO}_{2}$ on the geomechanical and permeability behaviour of brown coal: Implications for coal seam $\mathrm{CO}_{2}$ sequestration. Int. J. Coal Geol. 2006, 66, 204-216. [CrossRef]

11. White, C.M.; Smith, D.H.; Jones, K.L.; Goodman, A.L.; Jikich, S.A.; LaCount, R.B.; DuBose, S.B.; Ozdemir, E.; Morsi, B.I.; Schroeder, K.T. Sequestration of carbon dioxide in coal with enhanced coalbed methane recovery: A review. Energ. Fuel 2005, 19, 659-724. [CrossRef]

12. Pan, Z.; Connell, L.D.; Camilleri, M. Laboratory characterisation of coal reservoir permeability for primary and enhanced coalbed methane recovery. Int. J. Coal Geol. 2010, 82, 252-261. [CrossRef]

13. Gibbs, J.W. On the equilibrium of heterogeneous substances. Am. J. Sci. 1878, 16, 441-458. [CrossRef]

14. Griffith, A.A. The phenomena of rupture and flow in solids. Phil. Trans. R. Soc. Lond. Ser. A 1921, 221, 163-198. [CrossRef] 
15. Perera, M.S.A.; Ranjith, P.G.; Viete, D.R. Effects of gaseous and super-critical carbon dioxide saturation on the mechanical properties of bituminous coal from the southern sydney basin. Appl. Energy 2013, 110, 73-81. [CrossRef]

16. Ranathunga, A.S.; Perera, M.S.A.; Ranjith, P.G.; Bui, H. Super-critical $\mathrm{CO}_{2}$ saturation-induced mechanical property alterations in low rank coal: An experimental study. J. Supercrit. Fluids 2016, 109, 134-140. [CrossRef]

17. Vishal, V.; Ranjith, P.; Singh, T. An experimental investigation on behaviour of coal under fluid saturation, using acoustic emission. J. Nat. Gas Sci. Eng. 2015, 22, 428-436. [CrossRef]

18. Ates, Y.; Barron, K. The effect of gas sorption on the strength of coal. Min. Sci. Technol. 1988, 6, $291-300$. [CrossRef]

19. Brady, B.; Brown, E. Rock Mechanics: For Underground Mining, 3rd ed.; Springer: Dordrecht, The Netherlands, 2004.

20. Jasinge, D.; Ranjith, P.; Choi, X.; Fernando, J. Investigation of the influence of coal swelling on permeability characteristics using natural brown coal and reconstituted brown coal specimens. Energy 2012, 39, 303-309. [CrossRef]

21. Kiyama, T.; Nishimoto, S.; Fujioka, M.; Xue, Z.; Ishijima, Y.; Pan, Z.; Connell, L.D. Coal swelling strain and permeability change with injecting liquid/supercritical $\mathrm{CO}_{2}$ and $\mathrm{N}_{2}$ at stress-constrained conditions. Int. J. Coal Geol. 2011, 85, 56-64. [CrossRef]

22. Perera, M.S.A.; Ranjith, P.G.; Choi, S.K.; Airey, D. The effects of sub-critical and super-critical carbon dioxide adsorption-induced coal matrix swelling on the permeability of naturally fractured black coal. Energy 2011, 36, 6442-6450. [CrossRef]

23. Ranathunga, A.S.; Perera, M.S.A.; Ranjith, P.G.; Ju, Y.; Vishal, V.; De Silva, P. A macro-scale experimental study of sub-and super-critical $\mathrm{CO}_{2}$ flow behaviour in victorian brown coal. Fuel 2015, 158, 864-873. [CrossRef]

24. Perera, M.S.A.; Ranjith, P.G.; Peter, M. Effects of saturation medium and pressure on strength parameters of Latrobe Valley brown coal: Carbon dioxide, water and nitrogen saturations. Energy 2012, 36, 6941-6947. [CrossRef]

25. Ranjith, P.G.; Perera, M.S.A. Effects of cleat performance on strength reduction of coal in $\mathrm{CO}_{2}$ sequestration. Energy 2012, 45, 1069-1075. [CrossRef]

26. Perera, M.S.A.; Ranjith, P.G.; Airey, D.W.; Choi, S.K. Sub- and super-critical carbon dioxide flow behavior in naturally fractured black coal: An experimental study. Fuel 2011, 90, 3390-3397. [CrossRef]

27. ASTM D7012. Standard Test Method for Compressive Strength and Elastic Moduli of Intact Rock Core Specimens un-der Varying States of Stress and Temperatures; ASTM International: West Conshohocken, PA, USA, 2004.

28. Vutukuri, V.S.; Lama, R.D.; Saluja, S.S. Handbook on Mechanical Properties of Rocks: Testing Techniques and Results; Trans Tech Publications: Bay Village, OH, USA, 1978; pp. 105-115.

29. Kuvaev, N.; Panchenko, D. Effect of moisture on the dynamic strength of brown coals. J. Min. Sci. 1975, 11, 220-222. [CrossRef]

30. Ranjith, P.G.; Jasinge, D.; Choi, S.K.; Mehic, M. The effect of $\mathrm{CO}_{2}$ saturation on mechanical properties of Australian black coal using acoustic emission. Fuel 2010, 89, 2110-2117. [CrossRef]

31. Oldenburg, C.M. Geologic carbon sequestration: $\mathrm{CO}_{2}$ transport in depleted gas reservoirs. In Gas Transport in Porous Media; Springer: Dordrecht, The Netherlands, 2006; pp. 419-426.

(C) 2016 by the authors; licensee MDPI, Basel, Switzerland. This article is an open access article distributed under the terms and conditions of the Creative Commons Attribution (CC-BY) license (http://creativecommons.org/licenses/by/4.0/). 